\title{
MONIKA FLUDERNIK
}

\author{
The Historical Present Tense Yet Again
}

Tense Switching and Narrative Dynamics in Oral and Quasi-Oral Storytelling 


\title{
The historical present tense yet again: Tense switching and narrative dynamics in oral and quasi-oral storytelling
}

MONIKA FLUDERNIK

\begin{abstract}
The following paper is an attempt to extend the recent findings of discourse analysis in the area of conversational storytelling by supplementing the more narrowly (text-)linguistic approach with theoretical and structural considerations inspired by the literary discipline of structuralist narratology. Rather than analyzing a new corpus of oral stories and drawing yet another set of conclusions from this new material, I will follow the methodology of my own discipline, narratology, in (mostly) relying on available corpora and subjecting these to literary and theoretical criticism. In doing so, I will pretend that conversational narratives are as worthy of sustained interpretative analysis as 'literary' works of art.
\end{abstract}

As Stanley Fish has noted in a recent response (Fish, 1990) to criticism of his 'Being interdisciplinary is so very hard to do' paper (Fish, 1989), interdisciplinary research usually fails to combine two disciplines into one; it usurps bordering areas into the magnetic field of its own theoretical and practical preoccupations. This portrait of interdisciplinary practice represents my own attitude towards linguistics, from which I keep receiving new ideas and models for the study of narrative. If I have decided to make my results availabe to linguists, it is because I hope some cross fertilization may take place for the other side as well. More liberal students of language who are willing to look at conversational narratives as narratives rather than texts will perhaps grant that oral storytelling might be determined by a more general narrative frame, a frame that determines the structure of stories and the functions of their linguistic properties.

A word is here due at the very start about the wording 'oral and quasioral storytelling' in the title. Like many other roughly equivalent terms this has its drawbacks. My theses involve a recognition that present-day conversational stories share a structure (and therefore the use of the 


\section{Monika Fludernik}

'historic' present tense) with certain 'literary' narratives. This structure can be defined as episodic, and it prevails in literary narrative up until the eighteenth century. Episodic structure dominates in medieval verse and prose tales and is common as late as the early eighteenth-century novel. During the eighteenth century, episodic structure is increasingly superseded by more discursive narrative forms and - in English literature at least - only survives in oral storytelling and in imitations of oral narrative in fictional dialogue. This history of the replacement of episodic narrative - eloquently proposed by Ermarth (1981) - can be argued to coincide with the replacement of verbal style by nominal style (Wells, 1960), or 'doric' by 'attic' prose (Halliday, 1987). In fact, Halliday makes an explicit connection between verbal and nominal styles on the one hand and the oral vs. the written on the other, linking 'verbal' doric prose to the accumulative mostly paratactic language of speech, whereas nominal attic prose is said to be intrinsically 'written'. Findings about the importance of the oral paradigm for early forms of written narrative have come in from analysts of epic poetry, many features of which can be described as remnants of a still-valid oral pattern that has been transferred into written form (Foley, 1985; Bäuml, 1985; Fisher, 1985). Particularly for medieval narrative, which was sometimes still composed for oral performance, the gradual development of oral storytelling into written genres can be traced convincingly, and Fleischman's recent study of the historic present tense in Old French (1990) heavily relies on this connection between the oral and its 'literary' adaptations. It is on the background of such evidence for continuing 'oral' patterning in written texts that I have decided to use 'oral' and 'quasi-oral' storytelling for 'natural' or 'conversational' narratives on the one hand and 'literary', 'written' narratives which adapt the oral model on the other. The facts clearly undermine the oral vs. written and literary vs. nonliterary binarities. Indeed, my approach presupposes that oral tales are as 'literary', that is to say as carefully constructed, as quasi-oral narratives, whose literary merit has long been acknowledged. This is not to say that any conversational narrative is as 'aesthetical', as 'good', or as 'complex' and therefore as worthy of sustained interpretation as literary narratives. However, once the specific techniques or oral storytelling have been recognized as together fulfilling the same functions as does the interplay of narrative techniques in the 'written' genres, there should no longer be any difficulty in substituting a continuum of forms and functions between the oral and the quasi-oral episodic narrative and in deepening our understanding of simple narrative forms across this artificial boundary.

A last remark on the validity of my results for languages other than English is also in order. I frequently refer to the French passé simple/ 
imparfait distinction as an analogue of the foreground/background dichotomy, and I also point to examples in German oral narrative. Moreover, comparisons are drawn between the uses of the historical present tense in present-day conversational stories and in Middle English and Early Modern English texts. I am in fact claiming that there is a common, general pattern of episodic narrative, at least for Indo-European languages, and that the historical present tense occurs at precisely specified points within this pattern in all these languages. However, since an examination of the validity of this thesis - which is based on my analysis of quoted material in various studies on the historical present tense can be undertaken only by qualified philologists of individual disciplines (the classical languages, Old Irish, Russian etc.), I will merely point out equivalences where I have had reason to suspect they exist. Moreover, in the framwork of a mere article, ramifications of the pattern that I will introduce and discuss cannot possibly be dealt with in sufficient detail. The extent of the pattern's validity will necessarily have to be addressed in a monograph.

\section{Orientation}

In 1981 Deborah Schiffrin published an influential study of tense switching in narrative, attempting to account for the vexing problem of the alternation in oral storytelling between past tense and present tense forms, commonly referred to as the issue of the 'historical' present tense. Schiffrin's study constitutes a major advance over earlier approaches to the subject because it relies on a functional text-linguistic framework of analysis. Although many of the aspects of Schiffrin's explanation and of my own model have been discovered in the philological literature, these studies have failed to account for the functional status of the historical present tense. Philological discussion of tense alternation tended to be on a sentence by sentence basis, or at best on a sequence of two sentences shifting from past to present, or present to past. Moreover, the philologists' criteria of analysis were widely disparate, ${ }^{1}$ and most explanations were 'essentialist', linking the historical present tense to the 'meaning' of the present tense in general. Hence, the recurrent claim for the 'vividness' of the device, which is proposed to render past events 'present' to the reader's eye - a thesis rejected by most serious scholars in the twentieth century (Fleischman, 1985; Comrie, 1986). All of these explanations are 'essentialist' because they presuppose that the historical present tense has one particular meaning or use, and they additionally imply that whenever the context is as specified, the present tense must (or should) appear. The 
underlying model for these claims is a one-to-one 'grammatical' relation between form and meaning in a specified context: the historical present tense as allomorph. Since it has, however, proved impossible to find one simple rule that will fit all individual sentences that occur in the (historical) present tense, the problem has naturally remained intractable.

Recent work in discourse analysis, among which Schiffrin's paper still holds preeminence, has escaped this philological deadlock in two ways. It has focussed on natural narrative exclusively - a useful decision because in literary texts there are many kinds of present tense verbs alternating with preterites. In particular, discourse analysts have decided to exclude from consideration the typically continuous present tense passages in the realist novel and in historical writings (from which the name 'historical' present is originally derived), concentrating instead on tense alternation, which is prominent in natural narrative. Nessa Wolfson's $(1978,1979,1981,1982)$ seminal work on what she calls the 'conversational historical present tense' (CHP) was the first to limit itself to oral narrative. The second, even more important decision has been to concentrate on the function of 'tense switching', a question that foregrounds both the switch into the present tense as well as of the switch back into the preterite. This allows for the switch into, and out of, the historical present to be seen as a signal, rather than a morphological category attributing intrinsic meaning to either present or past.

By concentrating on the question at which points within the tale the historical present tense occurs, Wolfson and Schiffrin were enabled to present some ground-breaking results. Thus, it has been ascertained that the historical present occurs only in what Labov (1972) calls the "complicating action' section of the narrative, and that it cannot be found in the sections called abstract, (embedded) orientation, or coda. Embedded orientation within the 'complicating action' sections, for instance, accounts for a large percentage of past tense clauses and thus for the switch back into the past tense. As regards the function of the historical present tense, Wolfson submits that is is one of several 'performative' features of oral narrative, occurring in conjunction with other performative devices such as direct quotation of protagonists' speech, gestures, exclamations, asides, expressive sounds, and sound effects. These linguistic techniques of performance are subsumed under the title of internal evaluation' in Labov's schema. ${ }^{2}$ Schiffrin does not decisively go beyond the frame of Labovian story structure and evaluative performance function.

Fleischman's (1990) study of medieval narrative and her model of the distribution of markedness among narrative tenses constitute an immeasurable advance over her predecessors. Fleischman relies on linguistic 
studies of foregrounding in narrative, which have demonstrated a crosslinguistic preference for the marking of plot-advancing narrative clauses (Hopper, 1979a and b; Hopper and Thompson, 1980; Chvany, 1984; Reinhart, 1984). Fleischman notes, first of all, that in the context of narrative, the preterite is the unmarked tense, so that present tense forms alternating with the preterite can be considered foregrounded or marked. In fact Fleischman extends the foreground/background schema to cover two separate planes within the narrative. Foreground can be marked separately both within the plot line (constituted by the narrative clauses of the story's complication section) and within the descriptive ("noneventive') background material. In modern French récit, narrative clauses of course come in the passe simple, whereas the backgrounded noneventives use the imparfait. However, in Old French the background descriptions in the earlier texts are also rendered in the passe simple. Fleischman illustrates that the present tense can function as a device of 'foregrounding' in both areas. This yields, on the one hand, the essentially perfective narrative present $\left(\mathrm{NP}_{\mathrm{a}}\right.$ ) within the succession of narrative clauses in the passe simple and the equivalent Italian and Spanish categories; and, on the other, the imperfective 'visualizing' present (NP $)$ that occurs as the foregrounded level in the descriptive sections of embedded orientation. ${ }^{3}$

Another distinctive advance of Fleischman over Schiffrin is her more extended use of Labov's narrative subcategories, reintroducing the notions of 'peak' and 'resolution', which Schiffrin had dropped from her analysis. This enables Fleischman to restate with more precision that the historical present frequently occurs at peak points of the narrative and switches back to the preterite for the resolution section. It has of course been noted for a long time (for instance, Heinze, 1924) that historical present tense narratives are framed by preterites both at the beginning and the end of the tale. The tense switching paradigm, however, makes it possible to link the switch into the preterite with the notion of 'resolution'.

Fleischman's (1990) is the best study of the historical present we have had so far, and it is particularly to be recommended for its very successful handling of the medieval French corpus - an area of scholarly deadlock for decades. However, even this model still fails to answer some basic questions. The notion of foregrounding does not help to explain why something is foregrounded in the first place, and why other narrative clauses are backgrounded as a consequence. Although Fleischman emphasizes the subjective nature of the narrative present of action (NP.), which she links to Labov's internal evaluation, the precise nature of this subjectivity remains somewhat vague. ${ }^{4}$ In particular, there is little sense 
of a dynamic progression of the narrative, since foregrounding is an intrinsically static notion.

\section{Incipit}

I will now propose a schema of plot line and off-plot line structure for natural narrative and will demonstrate how this two-level model accounts for tense usage in oral narrative. In addition it will be argued how, when storytelling developed into a predominantly written rather than oral form, this particular two-level construction had to be abandoned, resulting in an analogous modification of the tense signals in the text.

It may be necessary to specify at the outset that natural narrative consists of intonationally patterned 'idea units' (Chafe 1979), usually brief spurts of about five words each which are coordinated additively and paratactically in most cases. Segmentational units beyond these 'ideas' (which Chafe arranges on single lines) are crucially marked by pauses and hesitations as well as by pitch and volume factors. This is why, in natural narrative, foregrounding and backgrounding are achieved primarily be means of prosodic features rather than by syntactic means. In fact, Thompson's (1987) analysis of subsidiary clauses as typically backgrounded in written narrative demonstrates how the loss of prosodic markers required a new functional system for the structuring of narrative. Subordinate clauses are one means of backgrounding in the written form.

What I will call the plotline includes the following elements: the initial abstract and orientation sections; the incipit (the clause defining the onset of action by means of a temporal specifier: one day, on Monday etc.); the narrative clauses which are temporally ordered as well as high-tone background units within the complicating action span (see below); and the sections entitled resolution, final evaluation, and coda. Off-plotline are all parenthetical remarks - clearly marked off by pauses, lower volume and pitch as well as by increased or slow-down tempo. The off-plotline basically includes two kinds of elements - embedded orientation and commentary.

For instance, in the second of my two example stories (example 15), which I have entitled 'A Fisherman's Tale', the embedded orientation section (line 25) is set apart from the preceding and following discourse by relatively long pauses of $(0.79)$ and $(0.52)$ seconds respectively. Likewise, the commentatory aside about the superstitiousness of the local fishermen (units 45 to 47 ) is clearly set off by $(0.41)$ and $(0.60)$ second pauses. Hightone background clauses, on the other hand, are noneventive 
and the resolution sections. Incipit clauses are frequently marked by discourse signals such as - most commonly - so, or and:

(6)

$\begin{array}{lrl}\text { PL } & 1 & \text { [...] when I went to see it [the house], } \\ \text { T } & 2 & \text { the guy says to me, } \\ \text { rpt. } & 3 & \text { says 'we got a bid for thirty-three - thirty four,' } \\ \text { rpt. } & 4 & \text { says, 'If you bid thirty-five,' he says, 'You'll get it.' } \\ \text { RES } & 5 & \text { I said 'Okay, let me think it over.' } \\ & & \\ \text { PL(INC) } & 6 & \text { And I went home } \\ & 7 & \text { and I called up my wife's cousin } \\ \text { OFF } & 8 & \text { who's a realtor. } \\ & 9 & \text { Well his partner knows XYZ very well, } \\ & 10 & \text { so he called him up. } \\ & 11 & \text { The bid was for twenty-seven five! } \\ \text { RES } & 12 & \text { So I figured they could do the same thing I was going } \\ & \end{array}$
PL(INC) 13 So he calls me up the next day
OFF 14 and I figure,
15 'Look, I could always bid a little higher than the guy and work my way up.'

INC 16 So he calls me the next day

OFF 17 and I told my wife exactly what to say.

INC 18 So he gets on the phone

$T \quad 19$ and so my wife says [...]

(Wolfson 1978: 217)

This is from one of Wolfson's stories, which I have here rearranged into Labovian narrative clauses. My extract starts with the end of an episode (the resulatative $I$ said [= line 5] constitutes the episode boundary). The following episode concerns the narrator's findings about the actual house price bid - lines 6 through 12 . Lines 13,16, and 18 provide a triple incipit for the following section in which the shrewd bargaining strategy is then presented in stark detail. I have also indicated in Wolfson's text what I consider to be the plotline (PL) and off-plotline (OFF) sections. Additionally 'turns' (incidence, and incipit points) are marked by (T), and result sections by (RES). Note how the incipit can keep being deferred by 'false starts' (Polanyi, 1978).

More complex tales can therefore be demonstrated to string episodes together, framed by an initial orientation and a final end result-plusevaluation-plus-coda section: 


\section{ABSTRACT-Orientation\{[episode 1][episode 2]|...||...|\} evaluation-CODA $\uparrow$ incipit \\ resolution}

The distinction between plotline and off-plotline levels of oral narrative correlates with tense usage. In the off-plotline sections, that is to say in embedded orientation and commentary, the tenses relates deictically to the narrators's present moment of discourse. The present tense refers to the present, even in the embedded orientation, when there is an explanation of some general states of affairs which may still be valid at the time of the telling:

(7) a. So the Voodoo doesn',

b. it has the-p-grill blanked o:ff.

c. Y'know;

d. hh so it couldn' git 'ny air in the rad'er.

e. So on the freeway ( )

f. he overheats.

(Jefferson 1978: 238)

Line (b) explains some general properties of the Voodoo car which serve as embedded orientation. Commentary, of course, necessarily uses the ordinary discourse distribution of present and past tenses:

(8) They guy's a (trip) but yihkno:w,

He's sorta weird.

[...]

He's gotta forty Fo:rd,

(Jefferson 1978: 240)

Fleischman - in the wake of Chvany (1984) - claims that in narrative the past tense becomes the unmarked term of the present/past opposition. However, this applies only to the plotline, and even there only to the narrative episode proper as I have outlined it above, that is to say to the stretch between the incipit and the resolution sections. The two outermost frames; story-resolution and story-incipit, however, predominantly retain a deictic past tense. One can, in fact, argue that the initial incipit and final resolution sections are the macro-structural narrative frames and therefore constitute the boundary between the deictic and the 'adeictic' (Harweg, 1975). The past tense in the episodic parts of narrative would be adeictic in the sense that its pastness is understood from context. I hestitate to link the adeictic past on the plot line with what Hamburger (1973) has called the 'epic preterite' because she deals with literary texts exclusively, where the narrative past is not subjected to continual tense 
alternation. One consequence of the unmarked status of the story-internal past is its replaceability by morphemeless zero forms in some American dialects.

(9) Well, Julie come up to Doc's door and rung the bell and they was nothin' doin'. She rung it again and she rung it seven or eight times.

(Lardner, 1929: 31)

C'lumbus win the exhibition game, 3 to 2, whilst Magrew set in the dugout, mutterin' and cursin' like a fourteen-year-old Scotty.

(Thurber, 1969: 86)

Then the midget begun givin' us the ballyhoo. [...] Then him and Magrew begun to hoop and holler and nudge. [...] I seen 'em first at breakfast the next day, settin' opposite each other [...]

(Thurber, 1969: 90-91)

Since the historical present tense is also frequent in these two stories, the ambiguous forms can clearly be recognized as being functional preterites. Indeed, rung and begun may perhaps be considered dialectal morphological variants of rang and began, and seen of course generalizes from morphological anteriority (compare done get, for $g o t$ ).

\section{Turn}

Now what is the function of the historical present tense in this framework? I will argue for two functions which are interrelated, concerning the level of plotting or emplotment (Ricoeur, 1984) on the one hand, and the pragmatic storytelling frame on the other. In contrast to mere 'foregrounding', even as a subjective, 'evaluative' strategy, I propose to consider the switch into the present tense as a signal for a narrative 'turn' of events. The turn is important in terms of plot function because it marks, not only what is commonly regarded as the peak or climax of an episode, but also the experientially important and significant incidence (Fludernik, forthcoming a). For this reason the turn pragmatically signals speaker's subjective involvement in the story and it is, I maintain, a correlate of tellability (Labov and Waletzky, 1967) or reportability. The major occurrences of the historical present can be analyzed as marking the incident which cuts into a setting - in the well-known 'schema of incidence' (Pollak, 1960; Quasthoff, 1980). It has been noted again and again that the historical present tense frequently correlates with surprising turns of events, which are introduced by lexical markers such as all of $a$ sudden. and then, etc., as well as by syntactic inversion and propositional prepos- 
ing (Casparis, 1975). This is true already of Middle English and early modern English texts:

(10) Thus spoke she, when from sea they suddenly do hear A strong and horrid noise

(Michael Drayton, Polyolbion XIX, v, 139, as cited in Denk, 1948: 57)

At length it burst for spight, and out thear flies

(Denk: 54) $)^{5}$

However, as we have already seen in Wolfson's story of the house purchase (example 6), the historical present tense also frequently occurs at the incipit points of new story-internal episodes (Hopper, 1979a and b; Kinney, 1985; Webber, 1985). Once the notion of an important turn of events, be they surprising or not, has been conceptualized, it will cause no great disruption to transfer this 'turn' from the incidence point of a narrative section to the very incipit. The difference between an incidence turn and an incipit turn, which is as subjective as the speaker's decision to mark for turning point at all, consists in the placing of the present tense within the structure of the tale, and it directly depends on the balance achieved between the 'turns' on the one hand and the resolution sections on the other. Each episode necessarily closes with a result/ reaction portion which correlates with predominant shift into the preterite. The result/reaction point is significative as a switch into the preterite because it correlates across languages, with some interesting temporal features. Thus, in French the story-initial and story-final tense is the passé simple, and in spoken discourse the passé composé, whereas orientation and setting come in the imparfait. In German this correlates with the preterite for orientation, setting and incidence (where the French has the passé simple, the passé composé, or the historical present), and the perfect for the result/reaction point (Harweg, 1975; Fludernik, forthcoming b). Whereas the historical present highlights the turn and its tellable qualities, the switch back into the preterite (the German perfect) marks story 'point', the meaning of the story, the rational explanatory presentation of what has been described experientially in the setting/incidence part (For narrative 'point', besides Labov, see Polanyi, 1979 and 1985).

Here are a few examples of the significant switch into the preterite that mark result/reaction:

(11) As they were one day discoursing of these and such like affairs, a porter knocks and brings a letter; the muid receives it and brings it to her mistress who presently opens and reads its, but she had 
no sooner finished her reading, but she pretending to be amazed and affrighted cried out, 'I am undone,' and was so ready to fall into a swound that her servant was forced to apply things to recover her.

(Kirkman, 1961: 61)

And he looks up indigestion and he pulls out these pills and he says, 'It says take two.' [...]. So it says take two, I said 'Oh, I'll take one.' So I took one, [...] I took the pill and immediately I had relief.

(Wolfson, 1982: 50)

He taketh his leve, and she astoned stood;

In al hir face nas a drope of blood.

(Chaucer, 'Franklin's Tale', F 1339-1340)

It can in fact be argued that the one distinguishing feature of the historical present tense pattern is its co-occurrence with this switch into the preterite. Within the same tone unit this switch signifies result/reaction, whereas, going into the off-plot level, it signals embedded orientation.

So far I have accounted for the historical present tense at the incidence point and have argued that the 'turn' function becomes operative also for episode beginnings. It needs to be noted that the longer the story, the greater this marking function for episode beginnings. It is hence no wonder that episode beginnings make up for a high percentage of the historical present tense in literary uses of the historical present tense:

(12) She, being acquainted with the place and person, takes coach and goes thither, but first she provided herself of a convenient lodging [...]

(Kirkman 1961: 70)

So on a day, right in the morwe-tyde,

Unto a gardyn that was ther bisyde,

In which that they hadde maad hir ordinaunce

Of vitaille and of oother purveiaunce,

They goon and pleye hem al the longe day.

(Chaucer, 'Franklin's Talc', F 901-905)

There is one more supplementary use of the historical present in oral and quasi-oral narrative that I wish to discuss, the historical present for the setting, as I have called it, i.e. for the state of affairs which is intruded 
upon by the incidence (Fludernik, forthcoming b). This typically constitutes a device of suspense, heightening the subjective and experiential quality of the story:

(13) Pearl stands there motionless as a hitchin' post, and the ball comes in big and slow and high [...]

(Thurber, 1969: 104)

We're talking to the woman and the door's closed and locked now, and the guy in the next apartment bangs his door-bang!- and as he bangs his door, the vertical tumblers [fall down]

(Wolfson, 1982: 73)

\section{Recapitulation}

The schema of episodic narrative that I have presented above combines several levels of narrative apperception. Oral narrative and its quasi-oral applications rely on brief syntactic units, which are coordinated paratactically. In oral performance plot-line foreground and off-plotline background are distinguished intonationally, and emphasize a double-tiered structure of ongoing story and simultaneous commentary and explanation. On the plot-line the historical present tense structurally marks 'turns', at the same time foregrounding the tellability of these turns. Switches into the preterite on the plotline, on the other hand, signal narrative 'point' - the consequences, results and reactions that occur in the wake of turns. The notion of narrative peak or climax can now be aligned to an episode-internal 'turn'.

The model requires the analysis of whole stories because only a complete tale can be split into its episodes, and allows the positioning of incipits and incidence turns. Listening to oral narrative in fact engages the audience in a complex interpretative process in which a holistic and dynamic image of the tale is triggered by the structure. Because oral narrative is never continuous, interrupted by numerous off-plot asides, the historical present tense helps to foreground the structural and experiential features of the story, whereas the on-plot preterites dynamically link incidence to consequence and therefore to the tale's teleological meanings.

I will now turn to a story that Deborah Schiffrin presented in her 1981 paper and discuss how my categories apply to it.

I reproduce Schiffrin's notations, but have added line numbering to help identify specific clauses in the subsequent discussion. I also mark on-plot units by capital letters. (Schiffrin's small letters, which mark her plot-advancing Labovian clauses, are retained.) 


\section{All These Guys}

my notation:

evaluation \{

1 Oh it was so crazy

orientation

Abstract I

Episode One: lines 7-30

\section{Setting}

A 7

emb. or. $\quad\left\{\begin{array}{r}8 \\ 9 \\ 10\end{array}\right.$
I remember this.

Maybe I shouldn't say it now.

It was really a weird thing.

We were at camp

and we did this crazy thing.

We were all going out for lunch

ORIENTATION

Schiffrin's notation:

ABSTRACT

\section{it was our birthdays}

and we were C.I.T.'s

so we were allowed to.
report/ $\left\{\begin{array}{lll}\text { B } & 11 \text { a } & \begin{array}{l}\text { We borrowed } \\ \text { someone's car }\end{array}\end{array}\right.$

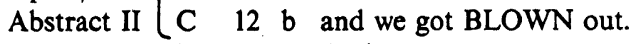
turn
D 13 c And w-
so, the car stalled
result E $14 \mathrm{~d}$ but we didn't ca-

COULDn't call

emb. or.

because we were

EMBEDDED

supposed t' be out

ORIENTATION

$t$ ' lunch

16 and why were we HERE?

17 Cause we had moved...

off the road t'party.

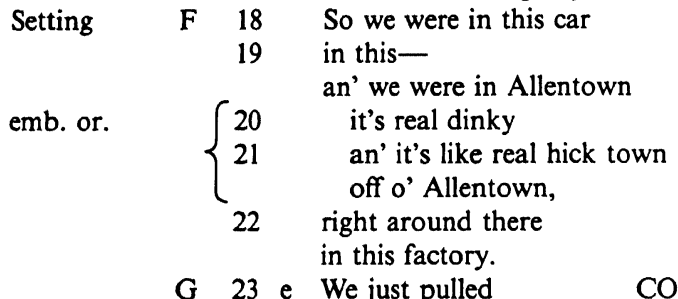

into this lot

COMPLICATING

ACTION

H 24 it was just

EMBEDDED

in this lot

ORIENTATION

turn

I $25 \mathrm{f}$ and all of a sudden the buzzer sounds 


\begin{tabular}{|c|c|c|c|}
\hline turn & $\mathrm{J}$ & & $\begin{array}{l}\text { and all these guys } \\
\text { hh come hh out }\end{array}$ \\
\hline esul & $\mathrm{K}$ & $27 \mathrm{~h}$ & and we didn't know \\
\hline $\begin{array}{l}\text { nb. or. } \\
\text { solution }\end{array}$ & $\begin{array}{l}\mathrm{L} \\
\mathrm{M} \\
\mathrm{N}\end{array}$ & $\begin{array}{l}28 \\
29 \mathrm{i} \\
30\end{array}$ & $\begin{array}{l}\text { cause we were stuck } \\
\text { So we asked some guy } \\
\text { t' come over an' HEL }\end{array}$ \\
\hline
\end{tabular}

Episode Two: lines 31-51

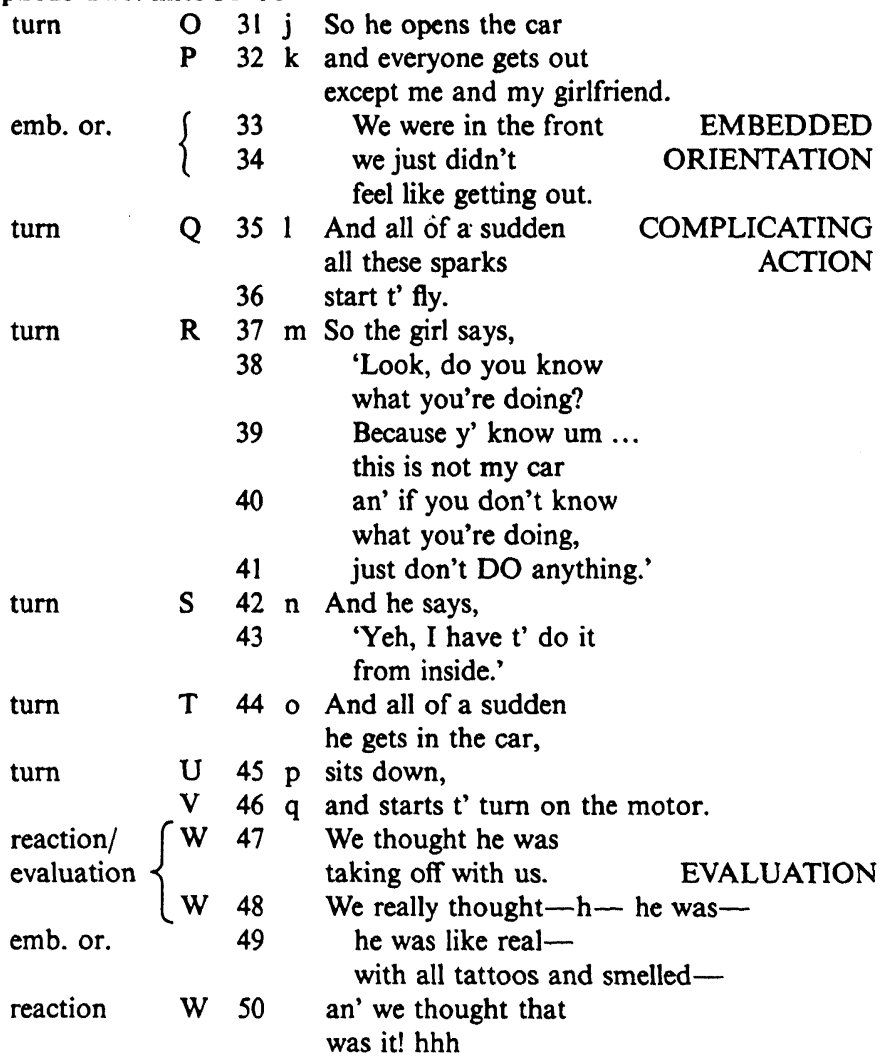




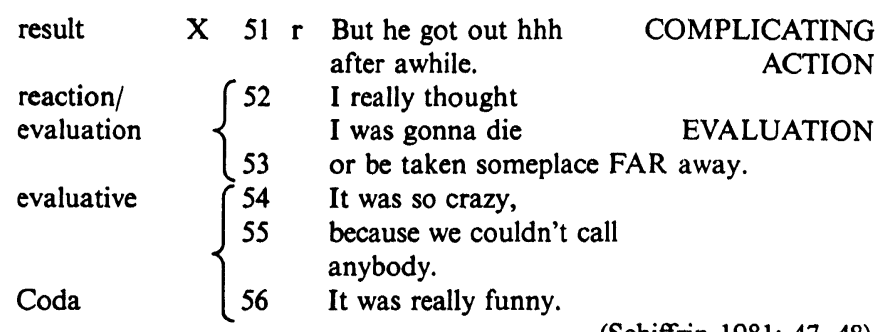

The story starts with a brief introduction (lines 1-4), in which suspense is created by referring to the adventure as 'a weird thing'. This is followed by an orientation section and an abstract of the main events, including some general background orientation (lines 8-10). The abstract reiterates the tellability signal 'We did this crazy thing', and enumerates some basic background data: the protagonists are at a camp (explaining some of the excitement of the adventure because they go against regulations in "partying off the road'), they are counsellors in training and hence allowed to go out for their birthday party. Lines 11-12 signal both the abstract of what basically happened - the car that they have borrowed breaks down - and it initiates the sequence of actions that constitute the storyline. Line 13 reflects a change in the speaker's decision on what to tell next. 'And $w$-' can either link with line 18, or - more likely - with line 23. The car breaks down, and then the car party is at the mercy of the people coming out of the factory. However, the speaker has to explain how they got into the lot in the first place, and she ${ }^{6}$ keeps retracing her steps to explain all the necessary situational factors involved. Since they had moved away from their official route, they could do nothing but pull the car into the lot.

So the speaker now gets back to narrating the events in their narrative sequence (line 13) - event one, the car stalls. This again requires some more background information both on the fix in which they find themselves, and on the whereabouts of the protagonists. (Note that the story never mentions how the party got on its way, or where they were going, so that some orientation is badly required at this point to fill in the missing links [lines 13-22].) Within this orientation section the speaker provides some 'generally valid' characerization of Allentown (in the present tense of the narrators's level), and she invents some constructed dialogue in free indirect discourse to account for the consequences of their lie: 'We were supposed to be out to lunch and why were we here? 
The major 'turn' of the story comes with 'and all of a sudden the buzzer sounds.' This onset of incidence is prepared for recurrently by a series of 'setting' sentences: 'so we were in this car in this [odd lot]' (lines 18-19), 'it was just in this lot' (line 24). The tellability of the story is connected with the scary nature of the narrator's experience. The sequence starts with the arrival of 'these guys', and the reaction of the car party (lines 29-30) (duly in the past tense), with some further embedded orientation (line 28). Note that lines 27 and 28 as well as 30 contribute towards the 'point' of the story, to its evaluation. The 'tellable' events of the adventure are the arrival of the 'guys' and the actions of the one that takes charge of the car. But the emotional impact (and hence meaning) of the events and the situation is given by - 'we couldn't call' (line 14), 'we didn't know what to do' (line 27), 'we were stuck' (line 28). The interim resolution of this predicament, rounding off episode one (started by 'all of a sudden'), is effected by definite action: 'so we asked some guy to come over and HELP us.' Note how the capitals on 'HELP', like those on 'BLOWN OUT' (line 12) signal a major emphasis, and the close of one story section.

Episode two starts with line 31, and introduces a long sequence in which all the narrative clauses are in the historical present tense, except for the evaluation (lines $47-48,50$ ) and the resolution (line 51). The sequence is interrupted by more embedded orientation (lines 33-34 and 49 ), and by a four-line constructed dialogue by the speaker's girlfriend. All the main actions in the narrative sequence are in the historical present tense, only the evaluation 'we thought he was taking off with us' and the (rather weak) ending 'But he got out after a while'. The real point of the story is the speaker's fear, which is reiterated in the narrative coda (lines 52-56), emphasizing the speaker's emotions.

The speaker is not a very seasoned storyteller. She has to overemphasize the tellability of the story, and she fails to clarify the 'point' (fear) in the early summary section. In particular, the introductory 'we did this crazy thing' (line 6), which seems to suggest an active prank, is misleading because the forbidden step, moving 'off the road to party' is mentioned only belatedly in embedded orientation. Once the speaker gets to the climactic scene the outing is backgrounded against the threat from the man whom they ask to help them. We in fact never learn whether the car got back to working order, or how the party got back to camp.

The episodic structure of the story is highlighted for the listener by means of the historical present tense, which foregrounds the scary incidences of the adventure. In parallel fashion, the 'point' of the tale receives heavy emphasis from the accompanying evaluative clauses that stress the practical and emotional fix in which the protagonists find themselves. 
The sequencing into episodes is additionally helped by the emphasis on one final term in each final clause of the respective sequence: 'BLOWN out', 'HELP', and 'FAR away'. Indeed the emphasis on 'FAR' leads me to evaluate the status of lines $52-53$ as a recapitulation of lines 48 and 50 , although - from their content - they appear to be part of the coda. This is additionally corroborated by the distinctive repetition of 'It was so crazy' (lines 1 and 54), which reiterates the tellability argument with which the narrator started out. Episode boundaries are morcover marked by the discourse signal so (lines $13,18,29,31,37$ ). This first initiates episode one ('so, the car stalled'), a false start (Polanyi, 1978), which becomes 'true' in line 18, 'So we were in this car', and which precedes the 'all of a sudden' highlight of episode one. So also marks the resultative 'So we asked', and 'So the girl says', and the beginning of episode two ('So he opens').

The story illustrates how the verbs in the historical present tense signal unexpected and emotionally memorable 'turns', reflecting the speaker's emotional involvement in the story - they are the tellable events. The past tense verbs, on the other hand, allow for the evaluation and logical coherence of the tale. Since the historical present emphasizes the tellable events (and tellability is a subjective factor), the speaker has of course a great latitude in deciding what he wants to highlight in this way, if anything. For this reason we find episode climaxes that have only one present tense marking a narrative incident, or a series of incidents, and there may also be a juxtaposition of the actions and utterances of two protagonists, since the tellability of the story resides in the agon between the two parties.

Sometimes the evaluation of the story is missing if it is quite obvious from the context. The story can then even end with the historical present tense, or the briefest of evaluative clauses in the past tense. See, e.g., Schiffrin's example story about the beating of the rat which turns out to be a sock (1987: 60). To illustrate this last pattern with a new tale, here is a story by a Flamborough (Yorkshire) fisherman, who goes out to fish with his friend. They encounter three nuns (who are supposed to bring bad luck), and they do have bad luck with a vengeance. The evaluative point is driven home by the final remark of the superstitious fisherman - "He says "I told you so." , The speaker may have wished to highlight both the reality of supernatural goings-on as well as the (uncomfortable) point that his friend is in the position to say 'I told you so' - an emotional key point of the adventure. I would like to thank Rosalind Tricker for the publishing rights and her help in transcribing the tale. ${ }^{?}$ 
(15)

\section{(A:)}

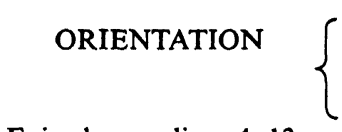

Episode one: lines 4-13

\section{EMBEDDED ORIENTATION}

(B:)

Episode two: lines 14-26

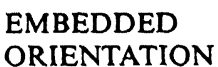

\section{A Fisherman's Tale}

1 I'll tell you a story

2 now about nuns (0.72)

3 John Chadwick (0.10) and meself (0.28)

were salmon fishing. (1.27)

I 4 And we went off at South Landing, (0.24)

5 and $(0.27)$ we would go (0.12) up towards Dan's [de:nz] Dyke, (0.33)

6 which is all salmon (0.16)

7 easy, (0.19) very easy (0.14)

8 pull net up beach. (0.37) Aye. (0.60)

II 9 Well when we got there,

III 10 it started to freshen on southerly, (0.15)

11 just a nice (0.22) strong breeze $(0.72)$

IV 12 He says 'Oh, are you going to bother?'

V 13 and I says 'Ah, ay,' (0.08)

VI 14 So he go out [goraut] (0.71)

VII 15 and he was dragging half a net up beach,

16 over his back [orr iz bak], (0.33)

VIII 17 and when he get to see how far up beach,

IX 18 he says, $(0.45)$

19 he stopped (0.10) and looked back, (0.12)

20 he was nae used to it, $(0.64)$

IX 21 he says 'what's them? (0.57)

22 What's that?' $(0.36)$

X/XI 23 And I looked (0.10) and I says

24 'Oh, three or four big old blue stanes.' [ste:nəz] 
Monika Fludernik

\section{EMBEDDED ORIENTATION REPEAT}

\section{RESULT}

\section{ORIENTATION}

(B:)

(A:)

$$
\begin{aligned}
& \text { [i.e. stones] (0.79) } \\
& 25 \text { 'twas raining you see, } \\
& \text { t'was blowing, (0.52) } \\
& \text { XI } 26 \text { I says, 'three or four (0.11) } \\
& \text { big blue storners' [sto:nəz]. } \\
& \text { (0.55) }
\end{aligned}
$$

Episode three: lines 27-40

XII 27 So (0.11) off he went again

28 with net over his back, $(0.40)$

XIII 29 and he said

30 'Don't pull it up beach.' (0.59)

XIV 31 And then he's had

another look up, and (0.34)

32 there were three nuns $(0.44)$

33 and they're all

(h)uddled together (0.71)

34 sheltering, $(0.23)$ you see, $(0.17)$

Oh, Ay.

35 with these $(0.48)$ capes [ke:ps] over them. (1.11)

XV 36 And he shouts (0.34)

37 'Hey $(0.85)$

38 The bloody nuns.' $(0.59)$

XVI 39 I says, 'Well, what about it?

40 We're all right.' (0.99)

Episode four: lines 41-49

XVII 41 So he come back

INDIRECT SPEECH REPEAT

XVII 43 he come back,

XVIII 44 and he says, (0.21)

45 'We shan't do any good now hauling net back.' $(0.41)$

EMBEDDED COMMENTARY
46 Ay (0.22)

"cause they were very religious, (0.03) very $(0.33)$ what $(0.39)$

47 oh, (0.10) supersititous, $(0.16)$ terrible $(0.60)$

XIX 48 And I says, (0.83)

49 'Ah don't be sae silly.' (1.03) 
Episode five: lines 50-66

\section{EMBEDDED ORIENTATION}

REPEAT
RESULTS
(lines 54-63)

aside

XX 50 We started $(0.12)$ to row off (0.04)

51 we had big cobber [kobor] anchored off moor (0.21)

52 shooting that out at little board $(0.67)$

XX 53 We started, we started rowing off $(0.20)$

XXI 54 and we brak(e) oar 55 (0.93) (laughter) Heh (0.73)

XXII 56 We got net half shod (0.26)

XXIII 57 and we had to scramble to t'other boat, 58 hadn't but one oar $(0.20)$

XXIV 59 We throw us [= our] net over [auər]. (0.53)

60 Before we got ashore,

XXV 61 t'was a southerly gale. $(0.08)$ eh $(0.58)$ huh (laughter) $(0.28)$

XXVI 62 We got covered in rain on coming ashore $(0.58)$

XXVII 63 and we lost half a net. (1.60)

CODA $=$ XXVIII 64 And that and then he says 65 'I told thou (0.14) thou shouldn't have gone 66 when them nuns was on beach.'

The story, which is included in a series of elicited stories about supernatural experiences, begins with an abstract (lines 1-2). The orientation section starts with line 3, with the first narrative event in line 4, and some further embedded orientation about the kind of fishing they would do and where (lines 6-8). The onset of the story proper is marked by well and a temporal specification ('when we got there'), and the fact that the wind springs up is mentioned - an argument in a commonsense explanation of what really happened. Episode one (presenting John's attitude to the fishing) is concerned with highlighting John's unwillingness to go on and the narrator's persistence in his aim. The highlighting is justified because the emotional impact of the experience is how John, who was less experienced, was actually right in his estimation of the situation, 
although he seems to be wrong because of his superstition. The end of episode one is signalled by a falling intonation more than by length of pause.

Now the second peak comes when John gets to sec the nuns and the narrator (deliberately??) identifies them as stones, trying to get John to continue with the fishing. The wrong identification is then 'motivated', i.e. explained, by a reference to the weather in embedded orientation (the narrator has as yet not given any hint that the weather had turned as bad as this).

The next episode is again marked by an initial so (line 27), highlighting that John looks again, a 'historical' present perfect tense ${ }^{8}$ (line 31 ), and the delayed orientation that the three stones were actually three nuns huddled together. This is followed by another exchange between John and the narrator, in which John reiterates his unwillingness to go on fishing. The forms 'he come back' and 'won't pull net' (lines 36-37) are ambiguous temporally. ${ }^{9}$ Lines $46-47$ are the narrator's evaluation of the mentality of the fishermen in this area (delayed orientation and evaluation), and the highlighted sequence ends with the narrator's commonsense rejection of John's argument. This leads on into the resolution section, marked twice, as 'We started to row off' (line 50) and as 'We started rowing off' (line 53), with interpolated embedded orientation, and leads to the final resultant events (lines $54,56,57,59,62$, and 63), with some further background on the state of the weather (now a 'southerly gale'). And the evaluation is then highlighted by the narrator's 'defeat': John has the last word.

\section{Resolution}

I am now ready to formulate a number of programmatic theses about the historical present tense which will provide a theoretical framework for the above observations.

Thesis 1. There is no 'meaning' of 'the' present tense. The present is a purely morphological category.

Thesis one is meant to imply that (a) there is not one 'meaning' or 'function' of the present tense per se, and (b) that therefore specific uses of the present tense (such as the historical present tense) cannot be explained as 'signifying "present" relevance', "lifting past events into the "present" of the speaker's reporting' and the like.

Thesis 2. There is a specific pattern of the use of the present tense within oral storytelling. Literary occurrences of the historical present tense only 
partly repeat this oral pattern, but can be explained as an extension and application of it to written narrative. (See Fludernik, forthcoming a.)

Thesis 3. The historical present tense proper in oral storytelling alternates with other tenses of narration and with the narrator's commentatory and evaluative present tense.

Thesis 4. The historical present proper is an optional replacement of a 'narrative aorist' (Bal, 1985: 15).

Narrative Aorist: A narrative aorist signals a basic narrative unit or step within the sequence of the plot events. It is not a tense, but a narrative deep structural unit. Narrative aorists are preserved in a reasonably detailed summary of the plot. (The present in plot summaries is therefore conceptualized as punctual.) Like Labovian narrative clauses, narrative aorists are temporally irreversible, if understood to indicate successive rather than simultaneous incidences (cf. Labov's coordinate clauses). It should be emphasized that the term 'narrative aorist' does not indicate the existence of a separate morphological category, although in French or Ancient Greek there does indeed exist a properly narrative morphological category of this name. If the plotline events are said to be marked by a narrative aorist, this reflects the fact that narratives can transform basically imperfective plot material into 'perfective' narrative aorists if required by the plot:

(16) g. and, going down the third time, I caught cramps

h. and I started yelling 'Help!'

i. but the fellows didn't believe me, you know,

j. they thought I was just trying to catch up because I was going on or slowing down

k. So all of them kept going.

1. they leave me

m. and so I started going down

n. Scoutmaster was up there

o. he was watching me

p. but he didn't pay me no attention either

q. and for no reason at all there was another guy, who had just walked up that minute

r. he just jumped over

s. and grabbed me

(Labov and Waletzky, 1967: 24) 
'They leave me' (line 1 in example 16) constitutes a clear 'turn' of events, even though leaving is usually regarded as an imperfective verb.

Thesis 5. Oral and quasi-oral narrative is episodic, and stories are structured as a series of story-internal episodes.

Thesis 6. The beginning of the story, which I have termed incipit - after the abstract, if there is one, and after orientation (unless orientation is delayed) - is signalled by a narrative aorist, frequently in conjunction with any or all of the following accompanying signals:

- hesitation, pause

- boundary of discourse markers: so, anyway

- specific (deictic) time reference (yesterday; at 4 p.m.; in 1955)

- specific (adeictic) time reference: one day (one time); when I was down there...

- subject-verb inversion, prepositional preposing etc.

Thesis 7. The story-frame is closed by the resolution-evaluation-coda section. These are all related in the narrative aorist. Story-internal episodes end with a reaction/result point in the aorist. This use of the narrative past marks out portions of the story that combine to make the 'point', which may or may not be expanded in the evaluation coda of the narrative.

Thesis 8. Delayed orientation sections interpolated with the plot narration are also in a narrative,past tense, but they are off-plotline and therefore cannot be equated with narrative aorists. In French, the imparfait fills this slot.

Thesis 9. The historical present tense can be employed to mark the incipit in the story-internal episodes, episode-internal settings and the incidences that impinge on those settings.

Thesis 10. Since the historical present tense is optional, the speaker decides which developments of the action to highlight. These are the events which, in his/her retelling of the story mark turning points and memorable plot sequences. It follows from this that much 'secondary' plot material, frequently in the telling of events leading up to the onset of tellable action (and the shift into the historical present tense) is narrated in the narrative past. The onset of tellable action may be marked additionally by the following signals:

- (and) suddenly, all at once, all of a sudden, etc.

- adverb preposing: and out comes this little sneak

- so 
- there may be a pause also in some stories, but this seems to depend on the kind of events related.

Thesis 11 .

(a) By highlighting tellable events in sequence the narrator provides a guideline for listeners, enabling them to keep track of the progression of the story. (This is necessary because oral narrative includes much delayed orientation and commentary by the speaker within the narrative sequence itself.)

(b) The use of the historical present tense marks involvement by the speaker in the story and additionally creates suspense for the audience. Using the past tense throughout signals an evaluating ('objective') stance in which the events are not structured for aesthetic and emotional effect.

Thesis 12. Besides the historical present tense proper oral narratives sometimes use uninterrupted series of the present tense for descriptive purposes. I call such passages a 'scene'. These persist in great number in nineteenth and twentieth century fiction and are usually considered 'historical' present tenses.

What I call the use of the present tense in a 'scene' roughly corresponds to Fleischman's 'visualizing' present and her 'historical present', that is to say the present tense in realist fiction, rather than in performed narratives.'

Thesis 13. Story units are signalled by intonation units, pauses, pitch, volume and tempo. Although I have no data base to check on this thesis, my intuitions on the basis of personal observation are as follows:

pauses: (a) There is a marked pause before the incipit point of the story. (b) There may be a slight pause before the turning point(s) marked by the historical present tense.

(c) There are usually (longer) pauses before and after commentatory and orientational off-plotline units, but such pauses can be reduced if the speaker is very involved in the telling of his past reactions to the outcome of the events.

intonational units: (a) There is a clear break before the onset of the story proper, i.e. after the initial orientation section, and this intonational unit continues throughout the episode into the switch to the past tense marking result or reaction, at which point the intonation comes to a low fall.

(b) The concluding evaluative sequence ends on a rising tone, presumably marking turn taking possibilities for the interlocutor(s).

pitch: The historical present marking narrative incidence (climax) comes 
with high pitch. Off-plotline comments usually employ lower pitch but may close on a rising pitch, signalling lifting to the on-plotline. volume: Highpoints in the narrative, but especially endings of subepisodes and episodes received extra emphasis by means of an increase in volume. asides: Delayed orientation and narrative commentary are set off from the progression of the tale by clear pauses, low pitch, and sometimes speeded up or expanded tempo, all ways of marking a contrast to the plot line.

dialogue. Recreated ${ }^{10}$ dialogue, if at the climax of the story, can be highlighted by repetition (of the punch-line), highest pitch point, volume and lengthening of syllables.

Since I am no linguist, the above can be little else than an indication of a listener's impressions. In particular, my results concern English oral narrative exclusively, and it is to be seen whether results in other languages coincide with this pattern. One of the problems that I have encountered with linguistic transcriptions of volume, pitch and prosodic contours is that it usually concerns 'sentence' units exclusively, whereas aural experience suggests a more comprehensive contourational structuring which I feel eludes current transcriptional practice. This is therefore an area where discourse analysis still has decisive break-throughs in store.

Thesis 14. Tense alternation is a tense metaphor in Weinrich's (1964) sense. It is the 'switch' - in conjunction with intonational outline, pitch, pauses (and tempo) - that signals the necessity of an interpretive move to the listener. There are therefore also examples where, for additional effect, tense is switched into an 'untypical' present or 'untypical past' to emphasize a change of direction, or highlight an even more tellable occurrence. This is the case, for instance, in the following sequence from Wolfson (1982), in which the onset of the story has been marked by the historical present tense (the safe arrival at destination in spite of having to sail against the wind), which initiates phase two of the anecdote. Once the events come to the turning point, the climax cannot be marked by the historical present tense because the environment is already in the present, and so we get 'and I said':

(17) Oh, yes, we decided to go to this pizza place for lunch so we sailed - we left at eleven in the morning and we got there at three, okay? Four miles - it was against the wind all the way. We get up to the place, we have our lunch, we get back in the boat, and I said to Bud, 'I think the wind died.' (Wolfson 1982: 36, my italics) 
Thesis 15. The historical present tense, self-evidently, since it occurs in oral narration, requires the presence of a speaker. This has an effect on literary recreations of the historical present tense. Literary historical present tense is therefore predominantly found in recreations of oral storytelling (Chaucer's Tales; in drama, letters, diaries and biographies.)

The historical present is also found - at one remove, and with a necessarily modified function - in literary prose that has a distinct teller character, whether in a quasi-autobiographical novel (Moll Flanders), or in an authorial novel, ${ }^{11}$ in which the narrator figure is realized as a fictionalized speaker separate from the world of the characters). The historical present tense, as a historical present, cannot occur in a narrative in the reflector mode, that is to say in a narrative in which events are filtered through the consciousness of a (or several) characters (Mrs Dalloway) or of a past self's consciousness (E. Gaines, 'The Sky is Gray'). Nor can the historical present tense occur in what is usually called 'camera eye' narrative, where events are presented in an 'objective' fashion. This does not mean that such novels cannot use the present tense at all. In fact both reflector mode narratives and camera eye narratives make frequent use of the narrative present tense. There is then no tense alternation: all verbs on the plotline are in the present tense (Frey, 1946). (An example of this would be Coetzee's Waiting for the Barbarians.)

Thesis 16. Says/Said Alternation. Since the function of the historical present tense is to highlight tellable events and their emotional impact on the narrator, the says/said alternation can frequently be explained by emphasizing events which happen to the narrator. (This accounts for the status difference in Johnstone's (1987) stories: the speaker is in the hands of the officer or corporal, and the story is about how s/he manages to survive/react in the situation.) The story may also emphasize the narrator's cunning, or active participation in the events (see Wolfson's housebuying story, 1978: 217-218; see example 6 above), in which case $I$ says, or says $I$ is much more common; or it may highlight the dynamics of interaction, allowing each participant a highlighted 'says', as in the Flamborough fisherman's story.

The concepts of tellability and narrative 'turn', vague though they are, greatly help to illuminate the vexed problem of says/said alternation. Tellable events are frequently those that describe the weird things that happen to the experiencer. Rather than being a mere device of participant tracking, the says/said alternation can therefore make some very subtle comments about the status of participants in relation to the 'point' of 
the story. It should also be noted, however, that influence from stories told exclusively in the present tense and from jokes, has helped to blur the dynamics of said/says alternation so that continuous series of says $I$, says he are quite common. In literature, moreover, this is a standard pattern already in Shakespeare and Defoe, since it mimetically recreates what is believed to be the colloquial standard.

Another aspect concerns the switching between past and present in an 'action plus saying' unit. (See Wolfson, 1979: 177-178, Fleischman, 1990: 165.) Although there are frequent cases when 'he went and said' are structurally marked as a unit by the common tense, in other circumstances there may be a shift in emphasis. Hence, from the examples quoted by Fleischman (165-166): ‘... he RUNS toward the lodging of Sir Bascol and said to him.' Here the past tense captures the resultative character of the action. On the other hand, in "He drove his spear through the middle of his chest, and then he says: "A heavy blow you have taken," the speech act is highlighted as a separate event. Wolfson discussed a number of such odd sequences. Since she does not provide more context, it is difficult to evaluate these data. As the 'point' of a story is crucially at issue, one needs to have full stories to test my model.

\section{Coda and evaluation}

I have argued in this paper that the historical present tense within the structure of oral narrative signals tellable events, dynamically relating them to statements in the preterite that guide the listener's evaluation of these events, marking the 'point' of the story. The present answer to the old question 'what is the function of the historical present tense' therefore relies on a narratological, discourse-oriented framework of storytelling. In this the present tense has no 'meaning', and it is not even conceived of as 'timeless', but simply marks a differential value in relation to the past tense. In this respect it is in no way different from the past tense itself, which marks the past in contrast to the speaker's present, usually in conjuction with an adverbial of time (Crystal, 1966; Huddleston, 1969). Once the story-telling session has been announced, tense functions in this differential manner, setting off speaker's asides from the narration of events.

In oral and quasi-oral narrative the presence of a speaker emphasizes the deictic contrast between the present and past tense forms, whereas within the narrative episodes the otherwise marked preterite is allowed to become unmarked. What I specifically add to this static schema of contrasting levels of markedness is the pattern which organizes or config- 
ures these contrasts dynamically in the interplay between subjective interest in plot progression (tellability) and endorsed evaluation to communicating meaning and 'point'.

\section{Notes}

1. They include, for instance, the aspect of the present tense verb, the position of this verb in a main or subordinate clause, including the specification of the tense in the previous sentence, the Aktionsart of the verb, the ingressive, descriptive, or semantic nature of the verb (mostly but not entirely overlapping with Aktionsart), as well as thematic and macrotextual considerations (the present tense in battle scenes and journeys; the present tense at the beginning, climax and end of episodes, chapters, or stanzas). (Graef, 1889, and Denk, 1948, are good examples of this.) Other proposals include the 'descriptiveness' of the technique, freezing the action at the climax of a scene (Herchenbach, 1977; Casparis, 1975); the suggestion that the historical present tense refers to actions which are in progress (Benson, 1967); that it occurs for perfective events only (Rolof, 1924; von Fritz, 1949; Fulk, 1987); that it is a stylistic alternative dependent on constraints of rhyme and meter (Visser, 1966). This wealth of individual 'rules' and explanations also required a large number of exceptions, which made the various 'solutions' to the problem even less convincing. Classical studies of the historical present tense also include Behagel (1899), Steadman (1917), Seidler (1968) for the Germanic languages, Rodemeyer (1889) for the classic languages, and Tristam (1983) for Irish. A classic narratological account is Stanzel (1959). Much valuable material can be found in Lindgren (1957).

2. Labov's evaluation category splits into external and internal. External evaluation comes in separate clauses; internal evaluation occurs within narrative clauses, including the use of intensifiers, repetitions, suspense-heightening coordinate and restricted clauses, and symbolic actions (Labov and Waletzky, 1967: 37-39). This schema is counterintuitive for narratologists, since the use of intensifiers or subjective lexis pointing to the narrator's evaluation of events is not intrinsically different from more extended evaluation in separate clauses. (See, for instance, Pugliatti's (1985: 193-194) discussion of Labov. What Labov may be getting at but does not directly specify is the difference between the narrating self and the experiencing self, split into latter-day evaluations and on-the-scene reactions and emotions.

3. It is regrettable to find Fleischman later reverting to an explanation of the present tense via its features of 'presentness', when she had earlier so laudably insisted on the nonintrinsic functional categories of markedness and foregrounding:

Conversational narratologists have convincingly demonstrated that a switch to the PR[esent] tense within diegesis functions as an EXPRESSIVE device for carrying out internal evaluation (Schiffrin 1981; Silva-Corvalán 1983). It allows the narrator to report events as if they were taking place simultaneously with their telling, in the fashion of a current report, so that members of the audience can see and hear for themselves what happened and interpret for themselves the significance of those events. Rather than interpret events for the listeners, the narrator allows events to speak for themselves, relying on more subtle linguistic devices including tense switching to do the work of evaluation. (Fleischman, 1990: 149; my italics) 


\section{Monika Fludernik}

This destroys the crucial insight that the use of the present tense is monitored, not by an essential property (or meaning) of the present (or the past, for that matter), but arises from the oppositional juxtapositions which Fleischman's markedness schema elsewhere so aptly manipulates.

4. In her chapter on what Fleischman (1990) calls the 'expressive' level of tense, she instead launches into a discussion of free indirect discourse and point of view. Fleischman's model is too complex to rehearse here in detail. It should be noted that her analysis relies on the perfectivity, semelfactivity, distancing and 'objective' realis status of the passé simple and narrative Present $\left(\mathrm{NP}_{\mathrm{a}}\right)$, a cluster of concepts that she deduces from the verbs' situation type (states, activities, accomplishments, and achievements a revised version of Aktionsarten). She also considers the temporal system on four textual levels (adapted from Jakobson via Halliday/Hasan (1976) and Traugott): the referential, textual, expressive and metalinguistic levels. Thus, on the textual level, the notions of linking (of events) and foregrounding are relevant, whereas on the expressivity plane the reality status of events, their perceived temporal distance from the narrating instance and their objectivity or subjectivity are at issue. The metalinguistic plane functionalizes diegesis or mimesis.

5. See also the examples quoted by Wolfson (1982: 40).

6. Schiffrin's paper does not specify the narrator's sex, and I would like to thank an anonymous reviewer for the clarification.

7. Thanks are due also to Professor Robert Howren, who clarified more phonetic uncertainties. I would also like to acknowledge gratefully the help of Professor Wallace Chafe, who contributed the measuring of pause lengths and made some useful suggestions about the outlay of the text.

8. The present perfect in English frequently takes the place of a historical present tense, when the accomplishment of an action can be interpreted as plot-advancing. The 'historical' present perfect was, to my knowledge, first described in Roloff (1924), and it is particularly common in Chaucer (Bauer, 1970; see also Wolfson, 1979: 171). Fleischman (1990) speculates about the uses of the perfect as a marker for episode boundaries. Although this does not seem to work for English examples, it may well have been true of the Old French texts she quotes.

9. Come is frequently used as a dialect variant for came (Schiffrin, 1981: 60, n. 14). See, however, my earlier remarks on morphemeless zero forms. The loss of $-s$ for the third person historical present is apparently quite common in at least American oral narrative (Myhill and Harris, 1988; Butters, 1988). It would make sense to argue that he come back is a zero-morpheme preterite (resulative) and that the present tense in won't signals a reported speech act.

10. Dialogue is not remembered verbatim, but recreated for purposes of artistic effect (see Tannen, 1980, 1987 and 1989; Johnstone, 1987: 34).

11. The term stems from Stanzel (1984) and designates a type of narrator who stands aloof from the world of fiction and comments on it from his (usually) omniscent perspective. The prototype for this is Henry Fielding's Tom Jones. The importance of a teller figure for the historical present tense was first recognised in Stanzel (1959) and Fries (1970).

\section{References}

Bal, Mieke (1985). Narratology: Introduction to the Theory of Narrative. Toronto: Univ. of Toronto Press. 
Bauer, Gero (1970). Studien zum System und Gebrauch der Tempora in der Sprache Chaucers und Gowers. Wiener Beiträge zur englischen Philologie, 73. Vienna: Braumüller.

Bäuml, Franz H. (1985). The theory of oral-formulaic composition and the written medieval text. In: Foley (ed.), 29-45.

Behaghel, Otto (1899). Der Gebrauch der Zeitformen im konjunktivischen Nebensatz im Deutschen. Mit Bemerkungen zur lateinischen Zeitfolge und zur griechischen Modusverschiebung. Paderborn: Schöningh.

Benson, L.D. (1961). Chaucer's historical present: Its meaning and uses. English Studies 42: $65-77$.

Butters, Ronald R. (1988). The historical present as evidence of black/white convergence divergence. In Proceedings of the Sixth International Conference on Methods in Dialectology, Alan R. Thomas (ed.), 637-649. Avon, England: Multilingual Matters.

Casparis, Christian Paul (1975). Tense Without Time: The Present Tense in Narration. Schweizer Anglistische Arbeiten 84. Berne: Francke.

Chafe, Wallace L. (1979). The flow of thought and the flow of language. In Discourse and Syntax, Talmy Givón, (ed.), 159-181. Syntax and Semantics, 12. New York: Academic Press.

Chaucer, Geoffrey (1987). The Riverside Chaucer. Larry D. Benson (ed.). Third edition. New York: Mifflin.

Chvany, Catherine V. (1984). Backgrounded perfectives and plot line imperfectives: Toward a theory of grounding in text. In The Scope of Slavic Aspect. Michael S. Flier and Alan Timberlake (eds.), 247-273). UCLA Slavic Studies, 12. Columbus, Ohio: Slavica.

Coetzee, J. M. (1982). Waiting for the Barbarians. [1980] King Penguin. Harmondsworth: Penguin.

Comrie, Bernard (1986). Tense and time reference: From meaning to interpretation in the chronological structure of a text. Journal of Literary Semantics 15 (1): 12-22.

Crystal, David (1966). Specification and English tenses. Journal of Linguistics 2 (1): 1-34.

Denk, Emilia (1948). Das Präsens historicum in der neuenglischen Poesie bis 1660 . Unpublished Diss., Univ. of Vienna.

Ermarth, Elizabeth Deeds (1981). Realism, perspective, and the novel. Critical Inquiry 7: 499-520.

Fish, Stanley (1989). Being interdisciplinary is so very hard to do. Profession 89: 15-22.

- (1990). Response. Paper delivered at 1990 MLA Convention, Chicago, Session 'The Discipline of Interdisciplinarity: Responses to Stanley Fish, "Being Interdisciplinary Is So Very Hard to Do." '.

Fisher, John H. (1985). Chaucer and the Written Language. In The Popular Literature of Medieval England, Thomas J. Heffernan (ed.), 237-251. Tennessee Studies in Literature, 28. Knoxville: The University of Tennessee Press.

Fleischman, Suzanne (1985). Discourse functions of tense-aspect oppositions in narrative: Toward a theory of grounding. Linguistics 23: 851-882.

- (1990). Tense and Narrativity: From Medieval Performance to Modern Fiction. Texas Linguistics Series. Austin: University of Texas Press.

Fludernik, Monika (forthcoming a). The historical present tense in English literature: An oral pattern and its literary adaptation.

- (forthcoming b). Narrative schemata and temporal anchoring. Journal of Literary Semantics 20 or 21 .

Foley, John Miles (1985). (ed.). Comparative Research on Oral Traditions: A Memorial for Milman Parry. Columbus, $\mathrm{OH}$ : Slavica.

Frey, John R. (1946). The historical present in narrative literature, particularly in modern German fiction. Journal of English and Germanic Philology 45: 43-67. 


\section{Monika Fludernik}

Fries, Ydo (1970). Zum historischen Präsens im modernen englischen Roman. GermanischRomanische Monatsschrift 51: 321-338.

von Fritz, Kurt (1949). The so-called historical present in early Greek. Word 5: 186-201. Fulk, R.D. (1987). The historical present in medieval Irish narrative. Zeitschrift für celtische Philologie 42: 330-343.

Gaines, Ernest (1976). The Sky is Gray. Bloodline, 83-117. New York: Norton.

Graef, A. (1989). Die präsentischen Tempora bei Chaucer. Anglia 12: 532-577.

Halliday, M.A.K. (1987). Language and the order of nature. In The Linguistics of Writing: Arguments Between Language and Literature, Nigel Fabb, Derek Attridge, Alan Durant, and Colin MacCabe (eds.), 135-154. New York: Methuen.

- and Hasan, Ruquaiya (1976). Cohesion in English. English Language Series, 9. London: Longman.

Hamburger, Käte (1973). The Logic of Literature. Bloomington: Univ. of Indiana Press.

Harweg, Roland (1975). Perfekt und Präteritum im gesprochenen Neuhochdeutsch. Zugleich ein Beitrag zur Theorie des nichtliterarischen Erzählens. Orbis 24 (1): 130-183.

Heinze, Richard (1924). Zum Gebrauch des Praesens Historicum im Altlatein. In Streitberg Festgabe, Direktion der Vereinigten Sprachwissenschaftlichen Institute an der Universität zu Leipzig (eds.), 121-132. Leipzig: Markert and Petters.

Herchenbach, Hugo (1911). Das Präsens historicum im Mittelhochdeutschen. Palaestra, 104. Berlin: Mayer and Müller.

Hopper, Paul J. (1979a). Some observations on the typology of focus and aspect in narrative language. Studies in Language 3 (1): 37-64.

- (1979b). Aspect and foregrounding in discourse. In Discourse and Syntax, Talmy Givón (ed.), 213-241. Syntax and Semantics, 12. New York: Academic Press.

Hopper, Paul J., and Thompson, Sandra A. (1980). Transitivity in Grammar and Discourse. Language 56: 251-299.

Huddleston, Rodney (1969). Some Observations on Tense and Deixis in English. Language 45: 77-86.

Jefferson, Gail (1978). Sequential Aspects of Storytelling in Conversation. In Studies in the Organization of Conversational Interaction, Jim Schenkein (ed.), 219-248. New York: Academic Press.

Johnstone, Barbara (1987). 'He says ... so I said': Verb tense alternation and narrative depictions of authority in American English. Linguistics 25 (1): 33-52.

Kinney, Clare (1985). The needs of the moment: Poetic foregrounding as a narrative device in Beowulf. Studies in Philology 82 (3): 295-314.

Kirkman, Francis (1961). The Counterfeit Lady Unveiled (1673). In The Counterfeit Lady Unveiled and Other Criminal Fiction of Seventeenth-Century England, Spiro Peterson (ed.), 1-102. Garden City, NY: Doubleday.

Labov, William (1972). Language in the Inner City. Philadelphia: Univ. of Pennsylvania Press.

— and Waletzky, Joshua (1967). Narrative Analysis: Oral Versions of Personal Experience. Essays on the Verbal and Visual Arts, J. Helms (ed.), 12-44. Seattle: Univ. of Washington Press.

Lardner, Ring (1929). Haircut. In Round Up. The Stories of Ring Lardner, 23-33. New York: Charles Scribner.

Lindgren, Kaj B. (1957). Uber den oberdeutschen Präteritumschwund. Suomalaisen Tiedeakatemian Toimituksia Annales Academiae scientiarum pennicae. Sarja-Ser. B, 112. Helsinki: Suomalaisen Kirjallisuuden Kirjapaino Oy Helsinki.

Myhill, John, and Harris, Wendell A. (1986). The use of the verbal -s inflection in BEV. In Diversity and Diachrony, D. Sankoff (ed.), 25-32. Amsterdam: Benjamins. 
Polanyi, Livia (1978). False Starts can be True. Berkeley Linguistics Society 4: 628-639.

- (1979). So What's The Point? Semiotica 25 (3-4): 207-241.

- (1985). Telling the American Story: A Structural and Cultural Analysis of Conversational Storytelling. Norwood, NJ: Ablex.

Pollak, Wolfgang (1960). Studien zum 'Verbalaspekt' im Französischen. Osterreichische Akademie der Wissenschaften. Philosophisch-Historische Klasse. Sitzungsberichte, 233, 5. Vienna: Verlag der Osterreichischen Akademie der Wissenschaften.

Pugliatti, Paola (1985). Lo sguardo nel racconto. Teorie e prassi del punto di vista. Critica letteraria contemporanea, 3. Bologna: Zanichelli.

Quasthoff, Uta M. (1980). Erzählen in Gesprächen. Linguistische Untersuchungen zu Strukturen und Funktionen am Beispiel einer Kommunikationsform des Alltags. Kommunikation und Institution, 1. Tübingen: Narr.

Reinhart, Tanya (1984). Principles of gestalt perception in the temporal organization of narrative rexts. Linguistics 22: 779-809

Ricoeur, Paul (1984). Time and Narrative. Vol. 1. Chicago, IL: Univ. of Chicago Press.

Rodemeyer, Karl Theodor (1889). Das Praesens historicum bei Herodot und Thukydides. Leipzig: G. Fock.

Roloff, Hans (1924). Das Prasens Historicum im Mittelenglischen. Gießen: Selbstverlag des Englischen Seminars der Universitäı Gießen.

Schiffin, Deborah (1981). Tense variation in narrative. Language 57 (1): 45-62.

Seidler, Franz W. (1968). Das Praesens historicum im Englischen. Die neueren Sprachen 17 (N.F.): $317-325$.

Silva-Corvalán, Carmen (1983). Tense and Aspect in Oral Spanish Narrative: Context and Meaning. Language 59 (4): 760-780.

Stanzel, Franz Karl (1959). Episches Präteritum, erlebte Rede, historisches Präsens. Deutsche Vierteljahrsschrift für Literaturwissenschaft und Geistesgeschichte 33: 1-12.

- (1984). A Theory of Narrative. Cambridge: Cambridge Univ. Press.

Steadman, J.M., Jr. (1917). The Origin of the Historical Present in English. Studies in Philology 14: 1-45.

Tannen, Deborah (1980). A Comparative Analysis of Oral Narrative Strategies: Athenian Greek and American English. In The Pear Stories: Cultural and Linguistic Aspects of Narrative Production, Wallace Chafe (ed.), 51-87. Norwood, N.J: Ablex.

- (1987). Repetition in conversation: Toward a poetics of talk. Language 63: 574-605.

- (1989). Talking Voices: Repetition. Dialogue, and Imagery in Conversational Discourse. Studies in Interactional Sociolinguistics, 6. Cambridge: Cambridge Univ. Press.

Thompson, Sandra A. (1987). 'Subordination' and Narrative Event Structure. In Coherence and Grounding in Discourse: Outcome of a Symposium, Eugene. Oregon, June 1984, Russel S. Tomlin (ed.), 435-454. Typological Studies in Language, 11. Amsterdam: John Benjamins.

Thurber, James (1969). You could look it up. In My World-And Welcome To It, 85-110. New York: Harcourt, Brace, and World.

Traugott, Elizabeth Closs (1982). From Propositional to Textural and Expressive Meanings. Some Semantic-Pragmatic Aspects of Grammaticalization. In Perspectives on Historical Linguistics, Winfred P. Lehmann and Yakov Malkiel (eds.), 245-271. Amsterdam: Benjamins.

Tristam. Hildegard L.C. (1983). Tense and Time in Early Irish Narrative. Innsbrucker Beiträge zur Sprachwissenschaft. Vorträge und kleinere Schriften, 32. Innsbruck: Institut für Sprachwissenschaft.

Visser, 1. Th. (1966). An Historical Sy'max of the Linglish Language. Vol. II. Leiden: Brill. Webber, Ruth H. (1985). Ballad openings in the European Ballad. In Comparative Research 


\section{Monika Fludernik}

on Oral Traditions: A Memorial for Milman Parry, John Miles Foley (ed.), 581-597. Columbus, $\mathrm{OH}$ : Slavica Publishers.

Weinrich, Harald (1964 [21971]). Tempus. Besprochene und erzählte Welt. Sprache und Literatur, 16. Stuttgart: Kohlhammer.

Wells, Rulon (1960). Nominal and Verbal Style. In Style in Language, Thomas A. Sebeok (ed.), 213-220. Cambridge, MA: MIT Press.

Wolfson, Nessa (1978). A feature of performed narrative: The conversational historical present. Language in Society 7: 215-237.

- (1979). The conversational historical present alternation. Language 55; 168-182.

- (1981). Tense-switching in narrative. Language and Style 14: 226-231.

- (1982). CHP: The Conversational Historical Present in American English Narrative. Topics in Socio-Linguistics, 1. Dordrecht: Foris. 